\section{Growth Control of 'Imperial Dark Blue' Plumbago with Ethephon, Flurprimidol, and Paclobutrazol Substrate Drenches}

\author{
Amy Barker, Ingram McCall, and Brian E. Whipker ${ }^{1}$
}

AdDitionAl INDEX wORDs. growth retardant, leadwort, Plumbago auriculata

Summary. Three plant growth regulators (PGRs) were applied as substrate drenches; paclobutrazol (1, 2, 4, or $8 \mathrm{mg} /$ pot $)$, flurprimidol $(0.5,1,2$, or $4 \mathrm{mg} / \mathrm{pot})$, or ethephon $\left(125,250,500\right.$, or $\left.1000 \mathrm{mg} \cdot \mathrm{L}^{-1}\right)$, plus an untreated control, to determine the efficacy of controlling excessive growth of 'Imperial Dark Blue' plumbago (Plumbago auriculata). No delay in flowering occurred with any of the PGR drenches, as compared with the untreated control. Plumbagos were responsive to both paclobutrazol and flurprimidol drenches. Concentrations of paclobutrazol and flurprimidol $\geq 1 \mathrm{mg} /$ pot resulted in shorter plant heights than the untreated control. For producers desiring a moderate to high degree of control, $1 \mathrm{mg} / \mathrm{pot}$ drenches of either PGR could be suitable. All flurprimidol and paclobutrazol concentrations greater than $1 \mathrm{mg} /$ pot resulted in excessive stunting and should be avoided. All ethephon drench concentrations were more consistent in controlling diameter, and increasing branching and flowering than paclobutrazol or flurprimidol. Based on the results of this study, the growth suppression of ethephon drenches was gradual, limiting overdose risks. Although plant diameters were not as small as plants treated with paclobutrazol or flurprimidol, diameter control was still adequate, and plants treated with ethephon drenches had a higher aesthetic appeal due to a more full appearance and increased flowering. With the use of an ethephon drench at 125 to $250 \mathrm{mg} \cdot \mathrm{L}^{-1}$, plumbago producers have another PGR available to control excessive stem elongation and improve the flowering of plumbago.

$\mathrm{P}$ umbago is a blue flowering shrub that grows to a height of $6-10 \mathrm{ft}$ and width of 8-10 ft (Gilman, 2011). This South African native (de Ruijter, 2008) is used for foundation and container plantings in zones 9-11, and grown in cooler climates as a tropical annual (Gilman, 2011). Its pale-blue flowers make plumbago a desirable landscape addition, but the growth habit in a conventional container environment tends to be uneven (Arnold and McDonald, 2001). Growers desire to control excessive shoot growth and increase lateral branching to produce a plant with greater market appeal (Arnold and McDonald, 2001).

Although a number of plant growth regulators (PGRs) have successfully been used to control plant height (Whipker, 2015), a limited number have been tested on plumbago. The current recommendation is to apply an ethephon foliar spray of $1000 \mathrm{mg} \cdot \mathrm{L}^{-1}$

Department of Horticultural Science, North Carolina State University, Box 7609, Raleigh, NC 276957609

We would like to thank SePRO and Fine Americas for donating the plant growth regulators and Sun Gro

Horticulture for donating the substrate used in this study.

${ }^{1}$ Corresponding author. E-mail: bwhipker@ncsu.edu. l week before pinching (Whipker, 2015). A previous study evaluated the effectiveness of paclobutrazol and uniconazole foliar sprays and drenches on plumbago (Arnold and McDonald, 2001). No statistically significant effects were observed in canopy growth or flowering with paclobutrazol applications. In a follow-up trial, higher paclobutrazol drench concentrations (40 to $80 \mathrm{mg} \cdot \mathrm{L}^{-1}$ ) resulted in severely stunted growth when the plants were transferred to the landscape and flowering was inhibited. Foliar sprays of uniconazole at 60 to $120 \mathrm{mg} \cdot \mathrm{L}^{-1}$ provided inconsistent growth control, affecting some plants while not others, resulting in no significant differences. No other research studies are reported on the effects of PGRs on plumbago.

Two additional PGRs applied as a drench have shown potential for successful growth control: flurprimidol and ethephon. Flurprimidol has been widely used in Europe since the 1990s and has undergone extensive research in the United States (Whipker, 2015). In a North Carolina State University study, flurprimidol effectively controlled the growth of 'Ellen Houston' dahlia (Dablia hybrid) when used as a 1 to $2 \mathrm{mg} /$ pot drench (Whipker, 2004). Pennisi (2014) tested the effectiveness of flurprimidol substrate drenches on five herbaceous foliage plants and found that it controlled growth in all but one species and intensified the plant colors as well. In addition, flurprimidol substrate drenches successfully controlled the growth of poinsettias in greenhouses, with vigorousgrowing cultivars requiring higher concentrations to achieve target heights (Currey and Lopez, 2011).

Ethephon has been primarily used as a foliar spray; however, approval for use as a drench application is pending U.S. Environmental Protection Agency approval (Whipker, 2015). In the North Carolina State University trials, substrate drenches have successfully controlled the growth of petunia (Petunia $\times$ bybrida) and geranium (Pelargonium $\times$ hortorum) with a target concentration of 125 to $250 \mathrm{mg} \cdot \mathrm{L}^{-1}$ (Whipker, 2015). A multistate study reported that ethephon "inhibited stem growth in nearly all of the bedding plants studied, although the magnitude varied among species and locations," although some species experienced delays in flowering (Miller et al., 2012). Both ethephon and flurprimidol substrate drenches have been found to be effective in controlling excessive plant growth and would be candidate PGRs to evaluate on plumbago.

This study has two objectives. The first was to determine whether a suitable lower drench concentration of paclobutrazol could be found, and second to evaluate the effectiveness of flurprimidol and ethephon drenches

\begin{tabular}{llll}
\hline $\begin{array}{l}\text { Units } \\
\text { To convert U.S. to SI, } \\
\text { multiply by }\end{array}$ & U.S. unit & SI unit & $\begin{array}{l}\text { To convert SI to U.S., } \\
\text { multiply by }\end{array}$ \\
\hline 29.5735 & $\mathrm{fl} \mathrm{oz}$ & $\mathrm{mL}$ & 0.0338 \\
0.3048 & $\mathrm{ft}$ & $\mathrm{m}$ & 3.2808 \\
3.7854 & $\mathrm{gal}$ & $\mathrm{L}$ & 0.2642 \\
2.54 & inch $(\mathrm{es})$ & $\mathrm{cm}$ & 0.3937 \\
28,350 & $\mathrm{oz}$ & $\mathrm{mg}$ & $3.5274 \times 10^{-5}$ \\
1 & $\mathrm{ppm}$ & $\mathrm{mg} \cdot \mathrm{L}^{-1}$ & 1 \\
$\left({ }^{\circ} \mathrm{F}-32\right) \div 1.8$ & ${ }^{\circ} \mathrm{F}$ & ${ }^{\circ} \mathrm{C}$ & $\left({ }^{\circ} \mathrm{C} \times 1.8\right)+32$
\end{tabular}


for controlling excessive plant growth without significantly delaying flowering.

\section{Materials and methods}

Rooted 'Imperial Dark Blue' plumbago cuttings [ 102 cell size (cell measured $4.5 \mathrm{~cm}$ deep $\times 2.3 \mathrm{~cm} \times$ $2.3 \mathrm{~cm})]$ were transplanted on 16 Jan. 2015 into $2.3-\mathrm{L}$ round plastic pots $(8$ inches diameter) filled with a soilless substrate consisting of (by volume) $80 \%$ peat and $20 \%$ perlite (Fafard ${ }^{\circledR} 1 \mathrm{P}$; Sun Gro Horticulture, Agawam, MA). Plants were fertilized as needed with a $13 \mathrm{~N}-0.9 \mathrm{P}-10.8 \mathrm{~K}$ water-soluble fertilizer at $150 \mathrm{mg} \cdot \mathrm{L}^{-1}$ nitrogen (Ultrasol Cal-Mag Seedling Plus; SQM North America, Atlanta, GA). Greenhouse day/night set point temperatures were $24^{\circ} \mathrm{C} / 18^{\circ} \mathrm{C}$. The plants were grown under natural daylengths.

The PGRs were applied on 13 Mar. Drench treatments consisted of paclobutrazol at $1,2,4$, or $8 \mathrm{mg} /$ pot (Piccolo 10XC; Fine Americas, Walnut Creek, CA), flurprimidol at 0.5 , 1, 2, or $4 \mathrm{mg} /$ pot (Topflor; SePRO, Carmel, IN), or ethephon at 125, 250,500 , or $1000 \mathrm{mg} \cdot \mathrm{L}^{-1}$ [corresponding to $22.18,44.36,88.72$, or $177.44 \mathrm{mg} / \mathrm{pot}$, respectively (Collate, Fine Americas)], plus an untreated control. These were applied using $6 \mathrm{fl} \mathrm{oz}$ of solution per pot and no solution was leached/drained from the containers after application. The experiment was a completely randomized design with seven single-plant replications. On the day of treatment, total plant height (measured from the pot rim to the uppermost part of the plant) was recorded. First flowering dates were recorded as plants bloomed. In the first week of May 2015, total plant height was again measured as well as plant diameter (measured at the widest dimension and turned $90^{\circ}$, and then averaged) was recorded.

Data for plant height, plant diameter, and first flowering date were tested with analysis of variance by general linear model (SAS version 9.3; SAS Institute, Cary, NC). First flowering date and plant height and diameter values were regressed using the PROC REG procedure to determine the bestfit linear or quadratic model for the paclobutrazol, flurprimidol, and ethephon drenches. Terms of the model were judged to be significant or nonsignificant and included in the final model based on a comparison of $\mathrm{F}$ values at $\alpha=0.05$.

\section{Results and discussion}

Paclobutrazol. The response of plumbago height to paclobutrazol model with the smallest plants being $24.3 \mathrm{~cm}$ tall when treated with $4 \mathrm{mg} /$ pot paclobutrazol, and were excessively stunted, being $42 \%$ shorter compared with the nontreated controls (Fig. 1A). However, there were no significant differences found among plants treated with different dosages and we attribute this to the PGR dosages used having reached the saturation point where no further control occurred and due to a large variations in plant growth. These dosage was best fit to a quadratic

results, variable height and excessive stunting, were also reported by Arnold and McDonald (2001) with paclobutrazol drenches. Future studies evaluating drench concentrations between 0 and $1 \mathrm{mg} /$ pot may result in smaller plants without excessive stunting.

Plumbago diameter was also best fit to a quadratic model (Fig. 1B). Excessive stunting was observed with all paclobutrazol concentrations. Plants treated with $1 \mathrm{mg}$ /pot of paclobutrazol were $48 \%$ smaller than the untreated controls. Concentrations $\geq 2 \mathrm{mg} /$ pot were all similar with respect to the degree of growth control,

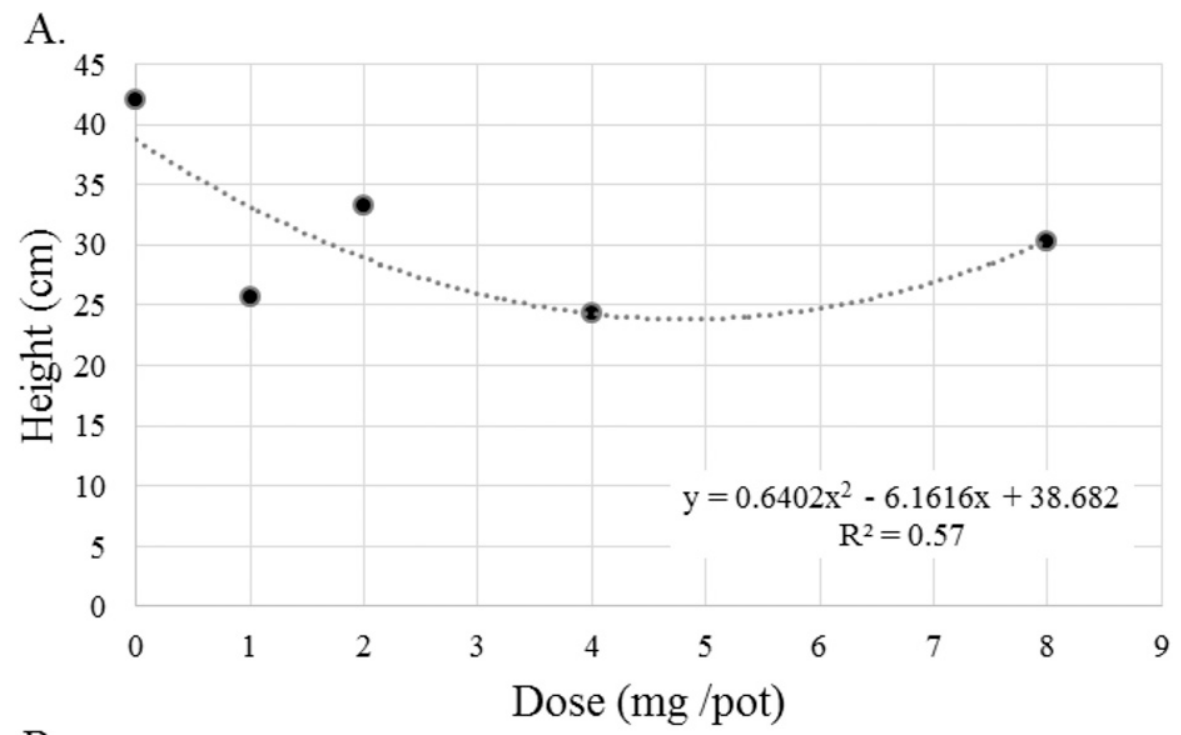

B.

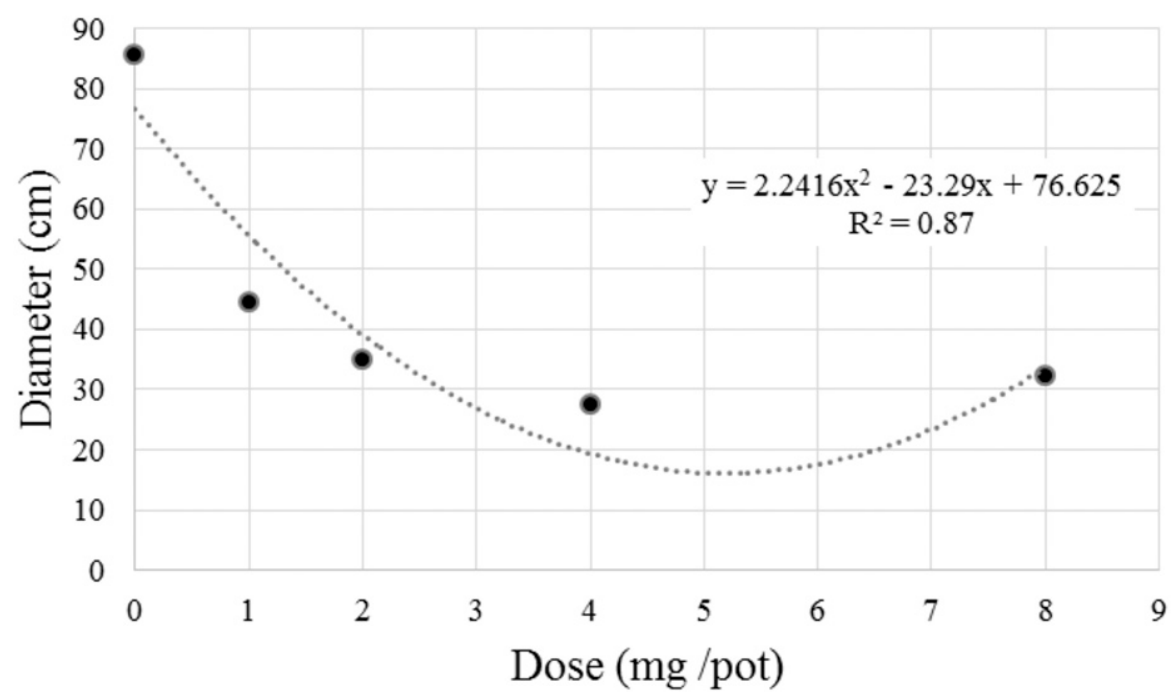

Fig. 1. Paclobutrazol substrate drench effects (A) 'Imperial Dark Blue' plumbago height $(B)$ and diameter. Plumbago cuttings were potted in Fafard ${ }^{\circledR} 1 P$ substrate (Sun Gro Horticulture, Agawan, MA) and received 0, 1, 2, 4, or $8 \mathrm{mg} /$ pot. Regression lines were generated from the best-fit model from the raw data. Each data point is the mean of seven plants; $1 \mathrm{mg}=3.5274 \times 10^{-5} \mathrm{oz}, 1 \mathrm{~cm}=0.3937$ inch. 
with the plants being $\geq 59 \%$ smaller, as compared with the untreated control. No differences were found among the first flowering dates of any of the paclobutrazol drench concentrations and the nontreated control, with the mean time until flowering after transplanting being $95 \mathrm{~d}$.

FLURPRIMIDOL. The response of plumbago height to flurprimidol dosage was best fit to a quadratic model (Fig. 2A). No height control occurred in the $0.5 \mathrm{mg} /$ pot flurprimidol drench concentration. Flurprimidol concentrations $\geq 1 \mathrm{mg} /$ pot resulted in significantly shorter plants $(\geq 30 \%)$, with no further increase in control as the concentration increased.

Plumbago diameter was also best fit to a quadratic model (Fig. 2B). Plants were $41 \%, 51 \%, 60 \%$, and $64 \%$ smaller in diameter when treated with $0.5,1,2$, or $4 \mathrm{mg}$ /pot of flurprimidol, respectively, when compared with the nontreated control plants. Control of diameter was considered excessive with flurprimidol concentrations $>1 \mathrm{mg} /$ pot. The use of flurprimidol drenches did not delay flowering, with the mean time until flowering after transplanting being $94 \mathrm{~d}$.

ETHEPHON. No significant differences were found among heights or first flowering dates with any of the ethephon drench concentrates or the nontreated control. The mean for plant height was $37.5 \mathrm{~cm}$ and the mean first flowering date was $96 \mathrm{~d}$ after transplanting. There was no difference in flowering dates compared with paclobutrazol or flurprimidol treatments or the nontreated plumbago. One possible explanation for the lack of significant height differences is that since ethephon does not affect shoot length to the same degree as the other treatments, more of the natural variation between plants was apparent. As the branches grew, they began to arch downward, and those not long enough to arch would measure taller than longer, bending shoots.

Plumbago diameter was controlled by ethephon drenches and best fit to a quadratic model (Fig. 3). The smallest plants averaged $53 \mathrm{~cm}$ width when treated with $1000 \mathrm{mg} \cdot \mathrm{L}^{-1}$ of ethephon. Plants were $16 \%, 24 \%, 30 \%$, and $38 \%$ smaller in diameter when treated with $125,250,500$, or $1000 \mathrm{mg} \cdot \mathrm{L}^{-1}$ of ethephon, respectively, when compared with the nontreated control plants. Unlike paclobutrazol and flurprimidol
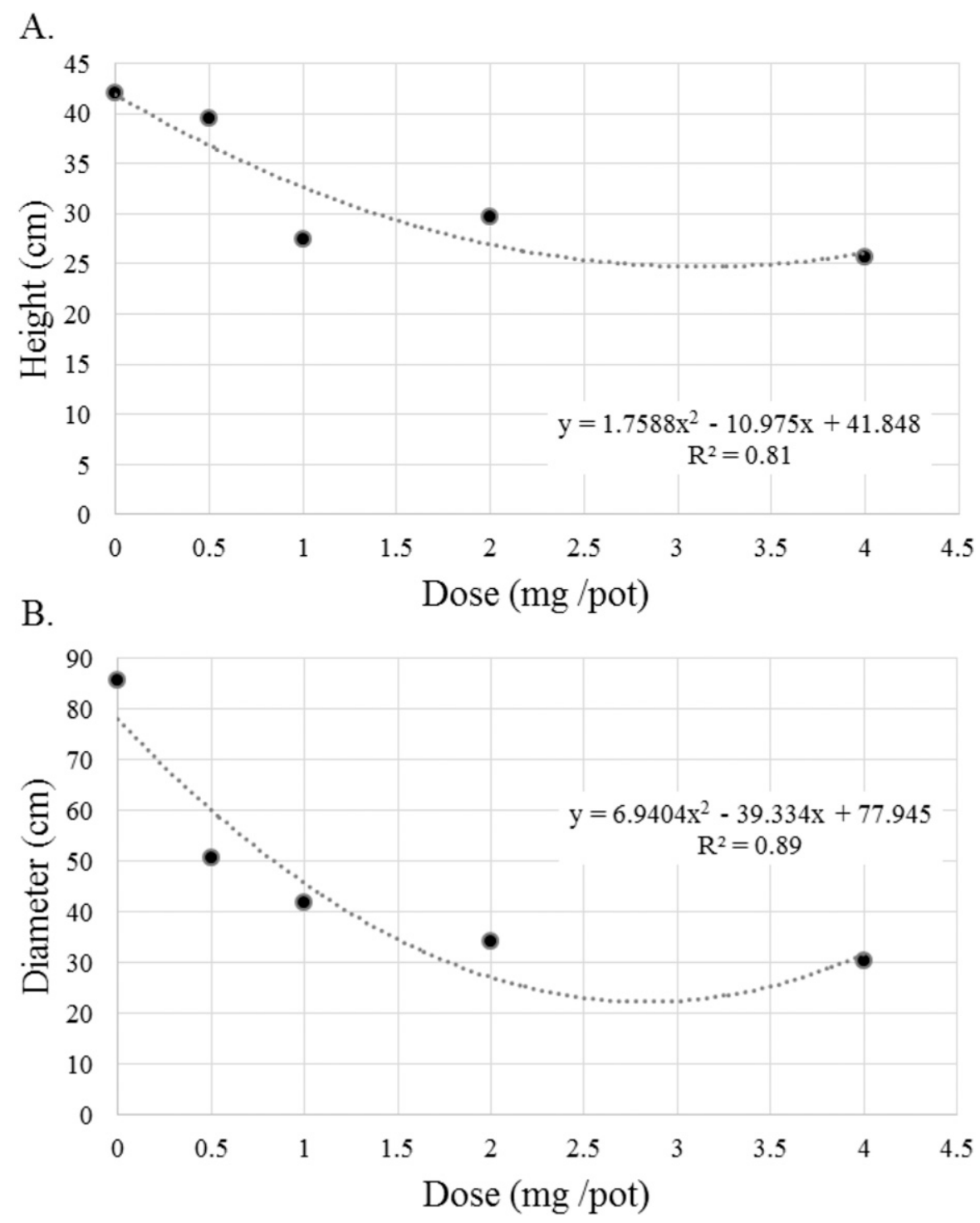

Fig. 2. Flurprimidol substrate drench effects (A) 'Imperial Dark Blue' plumbago height (B) and diameter. Plumbago cuttings were potted in Fafard ${ }^{\circledR}$ IP substrate (Sun Gro Horticulture, Agawan, MA) and received 0, 0.5, 1, 2, or $4 \mathrm{mg} /$ pot. Regression lines were generated from the best-fit model from the raw data. Each data point is the mean of seven plants; $1 \mathrm{mg}=3.5274 \times 10^{-5} \mathrm{oz}, 1 \mathrm{~cm}=0.3937$ inch.

results, an increase in lateral branching was observed as plant diameter decreased. This resulted in an increase of flowering inflorescences as the plants aged.

\section{Conclusions}

'Imperial Dark Blue' plumbago was responsive to anti-gibberellic acid (GA) inhibitors such as paclobutrazol and flurprimidol. As in the Arnold and McDonald (2001) study, plumbago plants treated with paclobutrazol drenches displayed excessive stunting and variable results. Although smaller diameters would allow wholesale producers to fit more plants in growing areas and shipping carts, excessive stunting reduces retail appeal at concentrations $\geq 2 \mathrm{mg} /$ pot. Similar results were observed with flurprimidol treatments $\geq 2 \mathrm{mg} /$ pot. The excessive stunting and high dosages reduced the benefits of using either in container nursery crops. If growers desire to have a high degree of growth control, $1 \mathrm{mg}$ /pot drenches of either paclobutrazol or flurprimidol would be the starting point for conducting their own trials.

Ethephon works with a different mode of action than the anti-GA PGRs paclobutrazol and flurprimidol that control cell elongation (Currey 


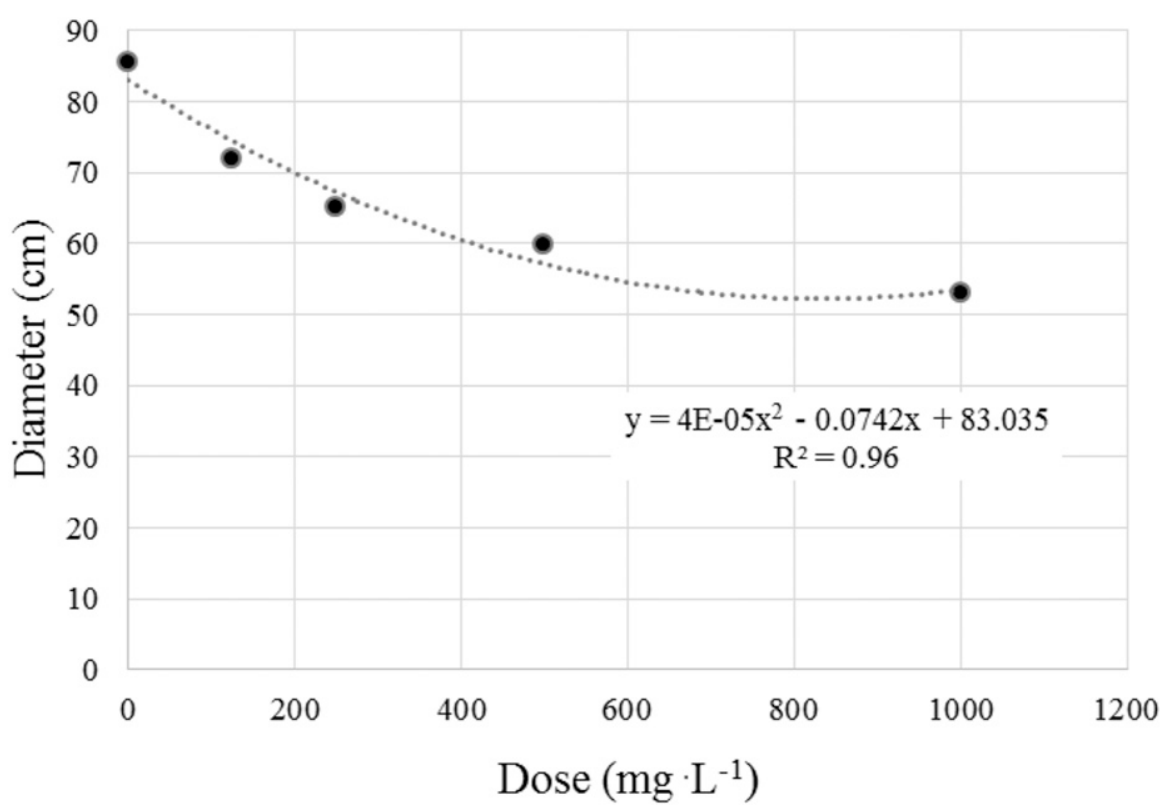

Fig. 3. Ethephon substrate drench effects 'Imperial Dark Blue' plumbago diameter. Plumbago cuttings were potted in Fafard ${ }^{\circledR}$ IP substrate (Sun Gro Horticulture, Agawan, MA) and received $0,125,250,500$, or $1000 \mathrm{mg} \cdot \mathrm{L}^{-1}$ (corresponding to $22.18,44.36,88.72$, or $177.44 \mathrm{mg} /$ pot, respectively). Regression lines were generated from the best-fit model from the raw data. Each data point is the mean of seven plants; $1 \mathrm{mg} \cdot \mathrm{L}^{-1}=1 \mathrm{ppm}, 1 \mathrm{mg}=3.5274 \times 10^{-5} \mathrm{oz}, 1 \mathrm{~cm}=0.3937$ inch.

et al., 2012). When ethephon is absorbed by the plant, it causes a change in the cell tissue $\mathrm{pH}$, resulting in ethylene gas being produced in the plant cells (Barrett, 2001). One beneficial PGR effect of ethephon is a diminished apical dominance and an enhancement of axillary shoots and inflorescence number. Ethephon drenches of 125 to $250 \mathrm{mg} \cdot \mathrm{L}^{-1}$ offer consistent control of plant diameter, improved branching, and increased inflorescences without delayed flowering. Based on the results of this study, the growth suppression of ethephon drenches were gradual. This limits the risk of overdosing the plants, which commonly occurs with paclobutrazol and flurprimidol drenches in a narrower range of doses. Although plant diameters are not as small as plants treated with paclobutrazol or flurprimidol, diameter control was still adequate, and plants treated with ethephon drenches had a higher aesthetic appeal due to a more full appearance and increased flowering.

Product costs are also an important factor that greenhouse growers take into account when making production decisions. The estimated chemical cost to treat 1000 pots with $6 \mathrm{fl} \mathrm{oz}$ of solution for $1 \mathrm{mg}$ paclobutrazol was $\$ 5.61,1 \mathrm{mg}$ flurprimidol was $\$ 31.31$, and $125 \mathrm{mg} \cdot \mathrm{L}^{-1}$ ethephon was $\$ 4.27$. The use of ethephon will help greenhouse growers by providing the most cost-effective method of controlling growth and increasing flowering of plumbago.

\section{Literature cited}

Arnold, M.A. and G.V. McDonald. 2001. Paclobutrazol and uniconazole applications affect production quality and subsequent landscape performance of blue plumbago. 9 Feb. 2015. <http://www.plantanswers. com/research_blue_plumbago.htm>.

Barrett, J. 2001. Mechanisms of action, p. 32-41. In: M.L. Gaston, P.S. Konjoian, L.A. Kunkle, and M.F. Wilt (eds.). Tips on regulating growth of floriculture crops. O.F.A. Services Inc, Columbus, $\mathrm{OH}$.

Currey, C.J. and R.G. Lopez. 2011. Early flurprimidol drench applications suppress final height of four poinsettia cultivars. HortTechnology 21:35-40.

Currey, C.J., R.G. Lopez, B.A. Krug, I. McCall, and B.E. Whipker. 2012. Substrate drenches containing flurprimidol suppress height of 'Nellie White' easter lilies. Hort Technology 22:164-168.

de Ruijter, A. 2008. Plumbago auriculata Lam, p. 472-473. In: G.H. Schmelzer and A. Gurib-Fakim (eds.). Prota 11(1): Medicinal plants/plantes medicinales 1. [CD-Rom]. PROTA, Wageningen, Netherlands.

Gilman, E.F. 2011. Plumbago auriculata plumbago, cape plumbago, sky flower. Univ. Florida Inst. Food Agr. Sci. Ext. FPS487.

Miller, W.B., N.S. Mattson, X. Xie, D. Xu, C.J. Currey, K.L. Clemmens, R.G. Lopez, M. Olrich, and E.S. Runkle. 2012. Ethephon substrate drenches inhibit stem extension of floriculture crops. HortScience 47:1312-1319.

Pennisi, B. 2014. Controlling growth in five species of herbaceous foliage plants. Univ. Georgia Ext. Circ. 925. 29 Oct. 2015. $<$ http://extension.uga.edu/publications/ detail.cfm?number $=\mathrm{C} 925>$.

Whipker, B.E. 2004. Topflor: A new plant growth regulator. North Carolina State Univ., Raleigh, NC.

Whipker, B.E. 2015. GrowerTalks: Plant growth regulators for annuals. Ball Publishing, West Chicago, IL. 